\title{
Interconnection of Concepts of Social Corporate Responsibility and Sustainable Development at the Current Stage of Economy
}

\author{
Aleksey Mikryukov*, Tatyana Chilimova, Anna Serebrennikova, Irina Sofronova
}

Ural State University of Economics, Ekaterinburg, Russia

${ }^{*}$ Corresponding author. Email:fbd-mav@yandex.ru

\begin{abstract}
At the present stage of development of society and economy, there is a clear trend of reorientation of business entities as a whole to obtaining a stable financial result by implementing the concept of sustainable development and the concept of corporate social responsibility, the question about clarifying their essential content, relationship and correlation arising. The paper deals with theoretical aspects of such concepts as "social corporate responsibility", "green energy" and "sustainable economy" in their interrelation. As a result, scientific and methodological fundamentals of the theory of sustainable development are determined from the point of view of the main schools of economics. Special attention is paid to the correlation of sustainable development and corporate social responsibility. It has been proved that the concept of corporate social responsibility has a narrower character in comparison with the concept of sustainable development and can be regarded as a tool for implementing the concept of sustainable development. The actual manifestations of the components of corporate responsibility are analyzed by considering introduction of green technologies by representatives of different sectors of the economy, banks included; stability of the economy increasing. It is revealed that modern society is undergoing a process of reorganization due to aggravation of social and environmental problems. The authors emphasize the importance of corporate social responsibility - an element of the company's corporate strategy - as a component of sustainable development
\end{abstract}

Keywords: corporate social responsibility, sustainable development, green energy, green investments, financial ecosystem.

\section{INTRODUCTION}

The issue of interconnection between corporate social responsibility (CSR), green energy and sustainable economy is quite relevant today and it is widely covered in academic and popular literature. When the system of environmental values of modern society (the so-called "green energy") is formed and the world community faces the task of improving the environmental situation and strengthening sustainable development (SD), the state does not always cope with its social functions, and business communities need an additional tool to increase their competitiveness, developing and implementing a competent CSR policy is a promising solution. Companies are no longer focused only on making profit, but also on establishing good relations with society and gaining sustainability in business. This is also evidenced by foreign practice. For example, numerous empirical studies based on the materials of markets of developed countries show that when conducting CSR systemic policies companies have an opportunity to gain an additional source of economic and environmental efficiency in the long term.

In Russia, today, CSR is being formed. Domestic companies, even if they demonstrate socially responsible behavior, do not consistently conduct the appropriate policy: there is no system that would lead to an increase in loyalty from various groups of stakeholders (stakeholder theory $[1,2]$ ) or to an increase in market valuation due to the perception of the company by the market as highly reliable (reputation theory $[3,4]$ ). These theories relate to the instrumental approach to CSR, according to which social responsibility is considered to be a tool for ensuring growing economic efficiency $[5,6]$. We cannot expect a significant effect of the CSR policy now. In this regard, the tasks of forming corporate social responsibility as a competitive advantage for the success 
of companies on the principles of combining the interests of "green energy" and sustainable development as interrelated elements of the corporate strategy are being actualized.

\section{MATERIALS AND METHODS}

The theoretical and applied basis of scientific research conducted in the studied field is a systems analysis of social and environmental problems, considered in terms of corporate social responsibility of business, business communities and commercial banks; the main provisions of structural and situational analysis as well as methods of synthesis, deduction and induction applied.

\section{RESULTS AND DISCUSSION}

The covid-19 pandemic has divided the global ESG agenda (Environmental, Social and Governance) into "before" and "after": today, issues of corporate governance and its social component are of paramount importance. The number of corporate structures positioning themselves as socially responsible and sustainably developed is growing exponentially, which is confirmed with the following:

- companies are increasingly publishing internal reports on their sustainable development in national and international registers [7];

- non-financial reporting standards related to sustainable development of companies are being made and introduced $[8-11 ; 12,13]$;

- sections on the aspects of socially responsible business appear on the web pages of corporate companies, and the goals of SD are declared at national and international expert business forums [14-16].

An analytical review of foreign and Russian scientific publications in the field of CSR, as well as corporate reporting of companies, has shown that today there is no generally accepted approach to the essence and content of SD, its principles and mechanisms. This is confirmed by an extensive list of relevant concepts, among which it is worth highlighting "sustainable development at corporate level" "corporate sustainable development", "sustainable corporate" "corporate sustainability", which leads to ambiguity in defining them. There is often a confusion of the concepts of "corporate social responsibility" and "sustainable growth of companies"; there is no "triune" concept in defining "sustainable development". The principles of sustainable development are being formally shifted to the micro-level (the level of a business organization).

This fact indicates an imperfect theoretical base in the scientific community, raising a number of questions about the essence of the concept of sustainable development of the company and its relationship with the conceptual aspects of environmental development and CSR. Conceptual foundations of such concepts as "social corporate responsibility", "green energy" and "sustainable economy" in their interrelation need to be developed.

It is worth noting that today the scientific community has already developed an extensive list of views on the essential characteristics of sustainable development, according to which SD "...meets the needs of the present generation, without contradicting the needs and aspirations of future generations" [17, p. 43].

The generally accepted approaches to SD include:

1. objective transition to $\mathrm{SD}$ and its recognition, interpretation of SD as a new model of socioeconomic development and response to emerging threats;

2. formation of the triune concept of SD, including economic, environmental and social components of development (this concept serves as a methodology for existing studies of sustainable development);

3. disclosure of problematic scientific aspects by including a micro-level (the level of a business organization), leading to a multi-level approach to the study of SD (global level, macro- level (national), regional level and microlevel(corporate) [18, p. 264].

Scientific research on the relationship of SD with the concept of CSR include the fundamental works of such scientists as W. Visser, J. Moon, J. Elkington, M. Epstein $[19,23,24]$..

The most accurate triune concept of SD is given in the works of an authoritative specialist on corporate responsibility and sustainable development - J. Elkington. The author proves that "... the condition for the sustainable development of society is the activities and strategies of companies in the economic, environmental and social direction corresponding to the expectations of stakeholders" [19, p. 165]. This provision was taken as the basis of a three-pronged approach to the concept of "corporate sustainability," which was subsequently reflected in the Non-Financial Reporting Disclosure Standards (GRI), SD standards at the international and national levels. In practice, the new version of basic standard BS 8900-1:2013 under the updated heading "Management of the Company's Sustainable Development" has become a reliable tool base for wide application. [11].

Regarding domestic science, it is worth noting that it was only in the 2000s when the scientific community began to study and discuss actively theoretical and methodological aspects of SD, attempts to study this discourse having been made before. For example, 
sustainability of companies at the corporate level, its environmental aspects were considered in the studies of K. Yu. Belousov, Yu. Blagov, A.V. Kanaev, E. V. Korchagin, A. E. Kostin, E. N. Kucherov, Yu. V. Myachina, N. V. Pakhomova, K. Richter, etc.

The review of domestic research has proved that at present there is no generally accepted scientific approach to either the content of SD, or its goals and mechanisms at the corporate level. The terminological apparatus proves to be vague - both "sustainable development of the company" and "sustainability of the company" are used. In most cases they are interpreted as economic (or financial) sustainable development, implying the achievement of stable economic and financial results of activities, which are actually one of the components of SD. Thus, there is a substitution of the subject matter of the study.

At the same time, there is a point of view widely spread in the scientific community, according to which sustainable development of a company can also be interpreted as a "microeconomic interpretation" of the original concept of SD [20, p.169]. In the first case, the subject matter of the study concerns sustainable development of society as a whole, in the second - the problems of sustainability at the micro-level (the level of a business entity). Thus, according to S. Turkin, "... a company can be stable if its activities allow all its stakeholders to achieve the desired future state" [21, p. $85]$.

However, though we agree with the above points of view, it should be emphasized that these postulates do not mean a formal transfer of the interpretation of "sustainable development of the company" from the macro-level to the micro-level in an unchanged form. Put simply, extrapolating the essential features, goals and principles of SD from the macro-level to the level of a business entity will lead to difficulties in finding business arguments stimulating businesses to transfer to sustainable development.

Thus, the ambiguity of the definition of SD, the incentive of the business community not only in practical recommendations in the field of $\mathrm{SD}$, but also in the development of appropriate strategies in the field of ecology and CSR, bring to the forefront the need to develop a set of relevant concepts of "social corporate responsibility", "green energy" and "sustainable economy", as well as a conceptual foundation for their interrelation.

In addition to the concept of CSR, both foreign and domestic business entities have begun to use such concepts as "corporate sustainable development", "corporate responsibility", "socially responsible business conduct", "corporate social activity"; issues of correlation of these concepts, their relevance, as well as their interconnection arising. Leading foreign experts in the field of CSR such as M. Van Marrewijk, J. Moon, R. Steuer, J. Elkington, etc. tried to find answers to these questions. In general, we can distinguish several characteristic features.

1. There is a dialectical connection between the concepts of CSR and SD, which consists in the fact that in both cases the role of business and its purpose in the economy, mechanisms of interaction between society and business, reassessment of corporate values, the need for business entities to be interested in solving environmental, social and economic problems and reducing emerging threats are shown;

2. The distinctive features of the concepts of CSR and SD are not particularly important and opposed to each other; both approaches are the fundamental basis of a business entity [22].

3. Methodologically, the concept of CSR and SD are at the same level, "related to the activities of a business entity", but there is a distinctive feature: CSR entails interaction with stakeholders, transparency of reporting, and SD involves creating company value, human capital, environmental management [23, p. 102].

4. The concept of SD is positioned as independent, alternative to social responsibility. At the same time, CSR, which includes the principles and mechanisms of SD, remains the initial concept [24, p.298].

It is obvious that supporters of the identified approaches point to the existence of a relationship between the concepts of CSR and SD.

Thus, we propose to consider the SD concept as the main concept of the company's development, capable of ensuring progressive financial development in the long term, the CSR concept being a related concept from the first stages of the SD concept. Besides, one should bear in mind the fact that the initial measures related to the implementation of CSR are costly throughout the entire period and begin to bring returns in a long time. At the same time, it should be noted that the concept of RD, in turn, has a noticeable impact on the concept of CSR. The costs of implementing CSR should not exceed the necessary costs for RD. The authors believe that the concept of CSR is narrower compared to the concept of $\mathrm{RD}$, which can be justified by the following:

1. The concept of CSR can be considered in the context of the company's interaction with stakeholders and is mainly aimed at improving social environment. The RD concept focuses not only on the current interaction with stakeholders, but also on the active development of the main activity of the company in order to obtain a stable profit in the long term. 


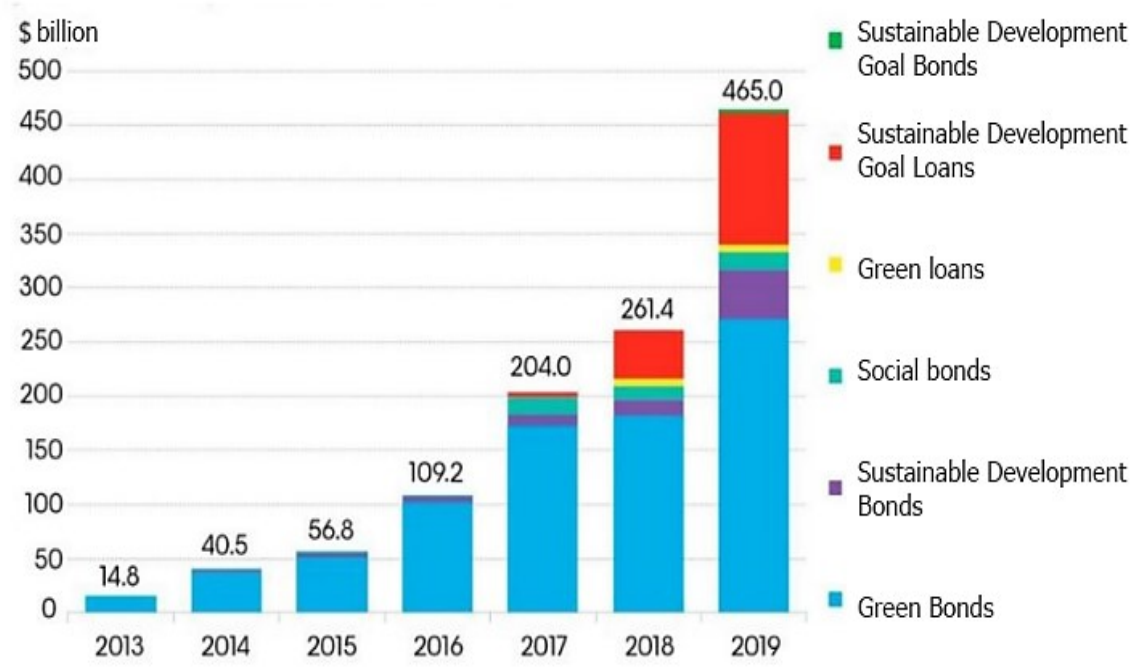

Figure 1 Dynamics of the issue of international debt instruments of sustainable development for 2013-2019*

Table 1. The composition of the MRRT index**

\begin{tabular}{|c|c|l|c|c|c|}
\hline № & Code & \multicolumn{1}{|c|}{ The name of the company } & $\begin{array}{c}\text { Capitalization, million } \\
\text { rubles }\end{array}$ & $\begin{array}{c}\text { Free- } \\
\text { Float }\end{array}$ & $\begin{array}{c}\text { Weight as of } \\
\mathbf{3 1 . 0 1 . 2 0 2 0 ,} \%\end{array}$ \\
\hline 1 & LKOH & PJSC "LUKOIL" & 4683608,00 & $54 \%$ & $15,6 \%$ \\
\hline 2 & SBER & PJSC "Sberbank" & 5444228,00 & $48 \%$ & $15,0 \%$ \\
\hline 3 & GMKN & PJSC "MMC" Norilsk Nickel "' & 3291506,00 & $38 \%$ & $14,0 \%$ \\
\hline 4 & GAZP & PJSC "Gazprom" & 5366785,00 & $46 \%$ & $13,7 \%$ \\
\hline 5 & NVTK & PJSC "NOVATEK" & 3508755,00 & $21 \%$ & $8,3 \%$ \\
\hline 6 & ROSN & PJSC "NK" Rosneft " & 5092424,00 & $11 \%$ & $6,3 \%$ \\
\hline 7 & TATN & PJSC "TATNEFT" them. V.D, & 1657984,00 & $32 \%$ & $6,0 \%$ \\
\hline 8 & MTSS & PJSC "MTS" & 652272,00 & $45 \%$ & $3,3 \%$ \\
\hline 9 & PLZL & PJSC "Polyus" & 1043713,00 & $21 \%$ & $2,5 \%$ \\
\hline 10 & ALRS & AK "ALROSA" PJSC & 590670,00 & $34 \%$ & $2,3 \%$ \\
\hline 11 & IRAO & PJSC "Inter RAO" & 603954,00 & $33 \%$ & $2,2 \%$ \\
\hline 12 & NLMK & PJSC "NLMK" & 827065,00 & $19 \%$ & $1,8 \%$ \\
\hline 13 & CHMF & PJSC "Severstal" & 763497,00 & $20 \%$ & $1,7 \%$ \\
\hline 14 & RUAL & United company "RUSAL" & 528641,00 & $16 \%$ & $0,9 \%$ \\
\hline 15 & TRNFP & PJSC "Transneft" & 256477,00 & $32 \%$ & $0,9 \%$ \\
\hline 16 & MAGN & PJSC "MMK" & 501839,00 & $16 \%$ & $0,9 \%$ \\
\hline 17 & PHOR & PJSC "PhosAgro" & 319736,00 & $25 \%$ & $0,9 \%$ \\
\hline 18 & RTKM & PJSC "Rostelecom" & 226593,00 & $32 \%$ & $0,8 \%$ \\
\hline 19 & AFKS & PJSC AFK "Sistema" & 176759,00 & $33 \%$ & $0,7 \%$ \\
\hline 20 & HYDR & PJSC "RusHydro" & 293628,00 & $19 \%$ & $0,6 \%$ \\
\hline 21 & FEES & PJSC "FGC EES" & 279330,00 & $48 \%$ & $0,6 \%$ \\
\hline 22 & AFLT & PJSC "Aeroflot" & 119280,00 & $41 \%$ & $50,0 \%$ \\
\hline 23 & RSTI & PJSC "Rosseti" & 318482,00 & $11 \%$ & $0,4 \%$ \\
\hline 24 & TRMK & PJSC "TMK" & 57504,00 & $30 \%$ & $0,2 \%$ \\
\hline
\end{tabular}

" compiled by the author according to [32]

2. The costs of CSR are usually carried out at the expense of the profit generated by the main activity, and they can constantly grow. Moreover, CSR activities influence production. When realizing the $\mathrm{RD}$ concept, a stable profit is formed which is a source of financing CSR activities. However, this profit can be obtained not only through the introduction of CSR, but also through other measures, for example, by increasing production efficiency, cost management. [36,37]

In turn, the concept of green economy, including energy, is, in fact, the basic component of implementation of the concepts of CSR and RD, since it 
involves the formation of a specific program aimed at achieving measurable results in the spheres related to both social responsibility of business and environment. In this aspect, "green" technologies and business models should be considered as a means that will provide a new impetus for economic growth that does not cause further damage to the environment, allowing to solve social problems e.g. by creating new jobs in the "green" sectors of the economy [25, p.35].

Today, almost all over the world, the principles of green economy are being implemented to a greater or lesser extent. Most countries understand the global trend associated with the energy transition and the need to transform not only their own economy, but also existing models of consumption and waste management [26, p.48]. $[27,28]$

The main goals of green energy are as follows:

- reducing pollution and waste generation by changing production and consumption patterns;

- meeting social needs through ways that can continue to be used indefinitely in the future without depletion of or damage to natural resources;

- developing and implementing alternative solutions to replace technologies doing harm to the environment;

- manufacturing products that can be reused or regenerated, thus creating a production cycle from start to finish;

- forming a center of economic activity focused on products and technologies useful for the environment, thereby increasing the speed of their implementation.

To achieve the set goals, "green" economy needs effectively working "green" financial instruments. According to the Association for the Development of Renewable Energy, in 2019, commercial banks issued "green" and "social" bonds amounting for US \$ 465 billion, which is $56.2 \%$ more than in 2018 (Figure 1).

* compiled by the author according to [29]

In contrast to the world practice, the domestic banking system is only at the beginning of this way: so far only a small number of Russian banks have attracted 7.55 billion rubles with "green" bonds that have received independent auditors' reports on compliance with the principles. It is worth highlighting PJSC Sovcombank, which was the first to issue "green" securities in the country. In 2020, VTB Capital Investments launched a project for responsible investment in corporate securities of Russian issuers whose ESG factors are integrated into the production process. The total volume of assets exceeded 2.8 trillion rubles. Sberbank Private Banking is currently implementing the third investment strategy corresponding to ESG principles, and, according to its estimates, the potential of the "green" bond sector in Russia until 2023 is 3 trillion rubles [30].

The Russian practice of developing the market of green finance and socially responsible investment can be said to have begun its countdown with opening a separate sustainable development sector on the Moscow Stock Exchange, aimed at attracting investment in socially responsible companies, i.e. in those companies that implement projects of environmental and social significance [31]. The MRRT index includes the oil and gas industry amounting for $50.9 \%$, metal mining $-24.1 \%$, the financial sector - $15 \%$, telecommunications- $4.1 \%$ (Table 1).

The most priority sectors are electricity, construction, transport and water (figure 2).

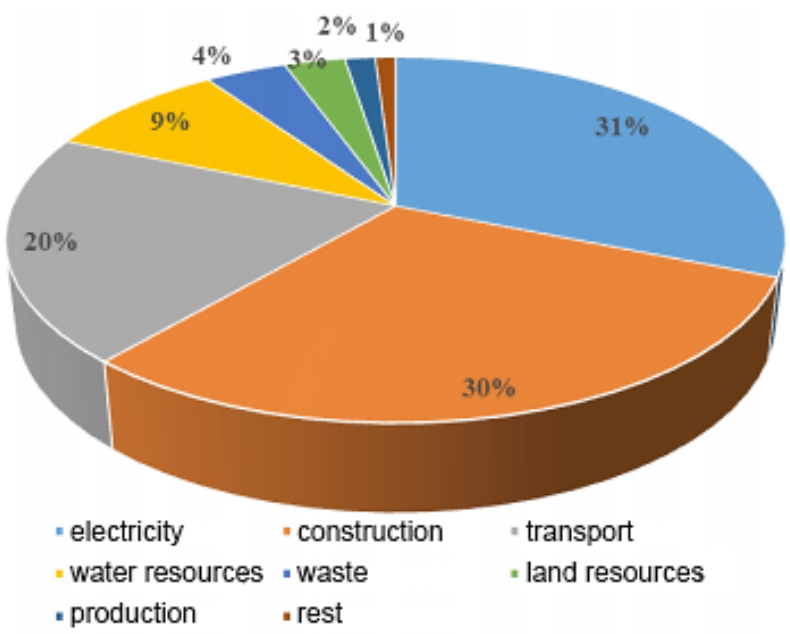

Figure 2. Industry distribution of green bonds in $2020^{*}$

* compiled by the author according to [33]

In the field of green energy, the dominant trend is the innovative development of hydrocarbon energy, with an insufficiently active development of power generation based on renewable sources. As world experience shows, it is the use of renewable energy sources that is much more efficient when electrifying remote areas that are disconnected from centralized power grids (and there are quite a lot of such regions in Russia, especially in the eastern part of the country). However, innovative methods of recycling are practically not developing though world practice shows their effectiveness. We would like to emphasize that waste disposal is a political and social task that requires active participation of government authorities, encouraging businesses to invest in waste processing enterprises, and formation of fundamentally new behavioral models among residents of the country. As for water resources, although Russia has no shortage of fresh water, its quality is deteriorating from year to year, and the "strategies", "programs" and "plans" adopted at the federal level have not yet produced noticeable positive results. The key reasons for this situation, in our opinion, are, firstly, the paradigm of 
Russia's development as one of the largest suppliers of hydrocarbons. Secondly, we lack investment resources for the development and implementation of innovative technologies [26, p. 79].

The most active participants in the green finance market - Sberbank and VEB are actively promoting investment projects in the housing and communal services sector: in water treatment, wastewater disposal, waste processing and sorting. The construction industry has a sufficient potential of green financing, namely in ensuring the energy efficiency of buildings and structures $[34$, p. 45-46]. No less interesting are projects related to energy efficiency in the field of urban lighting. According to expert estimates, the average project to improve the energy efficiency of urban lighting increases it by $50-75 \%$, in some cases - up to $85 \%$, which means a $50-75 \%$ reduction in fuel consumption, and hence harmful $\mathrm{CO} 2$ emissions. Projects to increase the thermal efficiency of standard series houses by creating individual heating centers, insulation of facades and roofs, reducing heat loss by a third, are also relevant. These projects will pay off economically in 5-7 years [26, p. 87].

Today, Sberbank has adopted a green agenda and actively supports environmental and social projects. For example, EcoStep LLC (Irkutsk), with the support of Sberbank, is doing a project in the field of eliminating tire dumps throughout the region in order to process car tires, materials subsequently used in the company's construction projects [35].

Thus, the issues of green financial technologies and their transformation have been widely discussed, both in professional circles and among a wide audience. Moreover, advanced economies are successfully implementing projects to form a new ecosystem of capital investments, which assumes the priority of environmental investments and the development of the segment of green bonds and other stock instruments. In modern realities, the paradigm of sustainable growth, green economy and social responsibility of business as fundamental management concepts is becoming more and more relevant and determines no less relevant issues related to the formation of a financial ecosystem that will ensure the progressive development of the world economy in the direction of green growth. Therefore, along with the state support aimed at improving the environmental and financial literacy of companies, especially small and medium-sized businesses, there is a need to develop an ecosystem approach that will ensure the interconnection of various tools for attracting green investments (venture financing, green credit, green bonds, crowd funding, etc.) at all stages of their implementation. In this regard, the ecosystem of green investments can be interpreted as a set of institutions, tools and strategic goals promoting green investments, and business conditions favorably affecting the growth of "green economy".

In our opinion, despite the short experience of green responsible financing, the Russian Federation has a sufficient potential for the formation of the national system of green CSR in terms of developing both methodological aspects and practical recommendations, taking into account the domestic specifics of sustainable economic development (Figure 3).

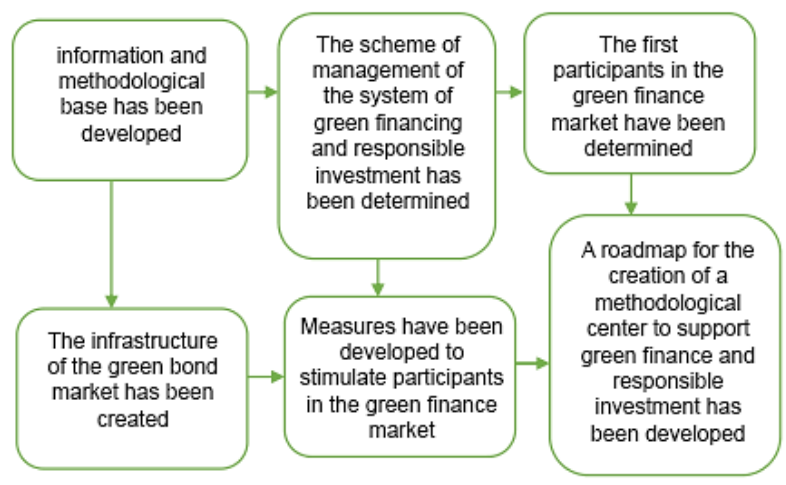

Figure 3. Results of activities on the development of the national system of green financing and socially responsible investment*

* compiled by the author according to [26]

Thus, the modern Russian practice of transforming the principles of environmental finance is based, among other things, on the developed global methodological recommendations and we are making effective steps towards building our national socially responsible ecosystem.

\section{CONCLUSION}

Today, the global community has set a vector for the transformation of the financial investment model and the development of new principles of responsible investment, which involves the formation of a new business ideology based on solidarity, social responsibility and economic efficiency of business. Each economic practice within a particular country should independently determine the criteria that can satisfy the interests of all stakeholders of socially responsible investment.

As the study showed, the concepts of CSR and SD, actively implemented in modern conditions, have a close relationship, the level of financing of events included. Moreover, the concept of SD is broader than the concept of CSR, and the latter can be considered as one of the tools for implementing the former.

The trends in the formation of a new management ideology and a paradigm for the development of human society today are closely linked with the goals of sustainable development, with the concept of green growth and, as a result, with the principles of responsible 
social investment, which determine the financial platform for post-pandemic global transformations. It should be noted that without the formation of an appropriate socially responsible ecosystem, a green investment market and a national model of environmental financing, it will be almost impossible to ensure a progressive transition and achieve sustainable development of business. In this regard, the formation of a system of methodological and financial support for the green transformation of investment relations based on corporate social responsibility is also more than relevant for Russian practice.

Summarizing the above, we would like to stress that Russia is quite confidently being involved in the process of forming a modern global ecosystem, systematically implementing the transition to ESG standards in all spheres. Forming a national model of socially responsible investment and green financing is the most important task of the current stage of development, the solution of which will ensure all conditions for the sustainable development of Russian society and green growth of the domestic economy.

\section{REFERENCES}

[1] R.E. Freeman, W. Evan, Corporate governance: a stakeholder interpretation, The Journal of Behavioral Economics, 19(4) (1990) pp. 337-359.

[2] M. Friedman, The social responsibility of business is to increase its profits, New York Times Magazine, 1970.

[3] R. Jones, A. Murrell, Signaling positive corporate social performance: An event study of familyfriendly firms, Business and Society, 40(1) (2001) pp. 59-78.

[4] S.A. Waddock, S.B. Graves, The corporate social performance-financial performance link, Strategic Management Journal, 18(4) (1997) pp. 303-319.

[5] A.V. Gizatullin, Corporate governance, social responsibility and financial performance of the company, Russian Management Journal, 5(1) (2007) pp. 35-66.

[6] L.E. Preston, D.P. O'Bannon, The corporate socialfinancial performance relationship. A typology and analysis, Business and Society, 36(4) (1997) pp. 419-429.

[7] Corporate Register-Global CSR Resources, www.corporateregister.com.

[8] British Standards Institution (2006). BS 8900:2006 Guidance for managing sustainable development. London, BSI Standards Limited.
[9] British Standards Institution (2009). BS 8901:2009 Specification for a sustainability management system for events. London, BSI Standards Limited.

[10] British Standards Institution (2013a). BS 89001:2013 Managing sustainable development of organizations - Part 1: Guide. London, BSI Standards Limited.

[11] British Standards Institution (BSI) (2013b). BS 8900-2:2013 Managing sustainable development of organizations, Part 2: Framework for assessment against BS 8900-1. Specification. London, BSI Standards Limited.

[12] National standard of Russian Federation (2011). GOST R 54598.1-2011. Enterprise management. Guidance for managing sustainable development. Moscow, Standartinform Publ.

[13] National standard of Russian Federation (2015). GOST R 54598.1-2015 Management of sustainable development. Part 1. Guide. Moscow, Standartinform Publ.

[14] Rio+20. Corporate Sustainability Forum Overview and Outcomes: Summary Report. (2012), https://www.unglobalcompact.org/library/1041.

[15] Corporate Register-Global CSR Resources, www.corporateregister.com.

[16] Forum RBC: Course for Sustainable Business development. Moscow, http://csr-ca.com/en/rbkforum-moscow-september-22/.

[17] Our Common Future, Report of the World Commission on Environment and Development. Oxford: Oxford University Press, p. 400 (1987).

[18] R. Steurer, M.E. Langer, A. Konrad, A. Martinuzzi, Corporations, stakeholders and sustainable development: A theoretical exploration, Journal of Business Ethics, 61(3) (2005) pp. 263-281.

[19] J. Elkington. Cannibals with Forks: The Triple Bottom Line of 21st Century Business. Oxford: Capstone Publishing Ltd, p. 402 (1997).

[20] J. E. Blagov, Corporate Social Responsibility: Evolution of the Concept. Sankt-Peterburg, Izdatelstvo SPbGu, 2010.

[21] S. Turkin, How beneficial it is to be kind, Alpina Business Books, p. 384 (2007).

[22] J. Elkington, Corporate sustainability. In Visser W., Matten D., Pohl M., Tolhurst N (eds.). The A to Z of Corporate Social Responsibility. London, Wiley, pp. 132-139 (2010).

[23] M. Van, Marrewijk Concepts and Definitions of CSR and Corporate Sustainability: between Agency and Communion, Journal of Business Ethics, 44(23) (2003) pp. 95-105. 
[24] J. Moon. The contribution of corporate social responsibility to sustainable development, Sustainable development, 15(5) (2007) pp. 296-306.

[25] S.I. Kodaneva, From "Brown Economy" to "Green". Russian and foreign experience. To Russia and the world in the XXI century, 1(106) (2020) pp. 46-66.

[26] S.I. Kodaneva, Green Economy - from comprehending the content of the concept to the practice of its implementation (the experience of Russia and foreign countries) RUSAYNS, p. 144 (2020).

[27] Green energy is developing, http://nzs-zs.ru.

[28] Investing in "green technology" - the future is now 2021, https://ru.talkingofmoney.com/.

[29] Association for the Development of Renewable Energy, 2021, https://rreda.ru.

[30] A Responsible Investment Fund has appeared in Russia, https://plus-one.rbc.ru/economy/fondotvetstvennogo-investirovaniya.

[31] Russia green finance: Unlocking opportunities for green investments, http: // documents1.worldbank.org/.

[32] Index of Responsibility and Transparency (MRRT), 2020, https://www.moex.com/s3019.

[33] Sustainable Debt: Global State of the Market 2020, https: //www.climatebonds. net/.

A. Bokarev, I. Yakovlev, L. Kabir, Green Investments in Russia: Search for Priority Areas, Financial Journal, 6(40) (2017) pp. 40-49.

[34] Baikal Bank of Sberbank - on the ESG strategy on the examples of "green financing" of enterprises in the Irkutsk region, https://press.sber.ru/.

[35] A.V. Mikryukov, Banking product as an indicator of the social responsibility of Russian banks. In the collection of works of the II All-Russian Scientific and Practical Conference.

[36] Financial and legal aspects of socially oriented investment (November 19-20, 2019). 